\title{
BAUDRILLARD VERSUS FOUCAULT: REVOLVENDO CONCEPÇÕES QUANTO À NOÇÃO DE PODER NA LITERATURA FOUCAULTIANA
}

\author{
DANiel de Oliveira GoMes ${ }^{1}$
}

\begin{abstract}
RESUmo: O presente artigo investiga, especificamente, a fixação crítica do autor Jean Baudrillard contra a noção de poder constante na literatura foucaultiana. Michel Foucault - um autor expoente do pósestruturalismo, muito examinado nos campos tanto da Literatura quanto do Direito - foi explorador do conceito de "poder microfísico", no qual os discursos políticos ou jurídicos não dariam mais conta de toda a gama de práticas de poder atuadas sobre os sujeitos sociais, ampliando o conceito de poder em várias obras e colocando-o na dimensão de uma nova abordagem. Baudrillard, por sua vez, considera o poder condenado ao desaparecimento decorrente da volatização do político. Tentamos notar as aporias do discurso de Baudrillard no livro em que se voltou contra Foucault, Oublier Foucault, em que tentou desmontar a literatura foucaultiana acerca do poder, explanando essa literatura como, ela mesma, uma espiral generativa de poder.
\end{abstract}

PALAVRAS-CHAVE: Foucault; Baudrillard; poder; escritura; literatura.

"Esta escritura (Foucault) é muito bela para ser verdade" (Jean Baudrillard)

\section{BAUDRILLARD VERSUS FOUCAULT}

Tentamos armar os nomes próprios de Michel Foucault e de Jean Baudrillard como personagens únicos dentro de toda uma "massa" de filósofos franceses que trabalharam a noção de poder desde os anos 60 até

Doutor em Literatura pela Universidade Federal de Santa Catarina (UFSC), com estágio em Paris. Professor adjunto de Literatura na Universidade Estadual de Ponta Grossa (UEPG), onde atua no Departamento de Pós-Graduação em Linguagem, Identidade e Subjetividade. Ponta Grossa, PR, Brasil. CV Lattes: http://lattes.cnpq.br/0593810363013174. E-mail: setepratas@hotmail.com 
hoje em dia. Uma das frases conhecidas de Michel Foucault, e mesmo "viralizadas" na internet, vem a ser: "Não me perguntem quem eu sou, não me peça para permanecer o mesmo". Nessa frase, de algum modo, Foucault já dizia, em outros termos, que não queria ser captado por um dispositivo que o tornasse dominado dentro dessa "massa". Para atingir a raiz desses filósofos, temos que nos reportar a um contexto passado. Quaisquer estudos sobre concepções de poder desde o pós-estruturalismo precisam saber que estarão a refratar inúmeras questões indômitas, bem como tomar em conta o clima de mudanças que vibraram os anos 70. Revoltas estudantis, revolução trabalhista, movimentos contraculturais, protestos de populações de carcerários que desencadearam grupos como o GIP (Grupo de Informações sobre as Prisões), movimentos de alto impacto no universo social e, por sua vez, no universo acadêmico conservador da época de uma França dos anos 60 que muito a abalaram, bem como uma noção estática dos intelectuais, uma noção de "permanência" de figuras acadêmicas que passou a ser impossível de se conservar como estavam, ou melhor, de se "pedir que permanecessem as mesmas", tomando o mote foucaultiano. $\mathrm{Ou}$ seja, houve situações históricas cujas intensidades dessegmentaram o "homo-academicus" de sua conjuntura de velho filósofo de gabinete universitário, colocando a nu o poder como prática intelectual. Tanto Foucault quanto Baudrillard constituem-se como dois autores sobre os quais incidiram toda uma revolução da subjetividade intelectual na Europa. O poder como uma noção sociológica, desde tais acontecimentos, passou a ser olhado como uma prática de si em novas amplitudes, que, hoje em dia, em certo sentido, passamos a homogeneizar, a ver como algo concebido longe de seus contextos. Não raro, já tomamos como assimilados certos aprendizados, já passamos por toda uma reestruturação de uma gênese social do que é o homem, por exemplo, em Michel Foucault, ou, no caso específico dele, do que "foi” o homem, de modo que essa "não definição", tal questão de um rumor que não se define, de uma sombra silenciosa, autodespersonalizada, acabou por ser algo coeso àquele tempo. Somos herdeiros dessas perspectivas que marcaram décadas.

Os objetivos do presente ensaio estão em considerar as relações e disparidades entre ess dois teóricos, de semelhantes influências e cujos trabalhos são muito estilizados acerca do tema do poder e de seus sentidos 
na sociedade (com seus múltiplos discursos e formas de coerções). Relações e disparidades, sobretudo, entre autores considerados criticamente, por vezes, próximos e, por outras, muito distantes em suas visões teóricas. O que iremos tentar escavar são as dissonâncias entre eles, no que tange ao tema do poder.

Buscaremos viajar, paralelamente, por uma multiplicidade de processos e de constituições que algumas vezes se aproximam no que se refere às noções de poder que eles sustentam. Quando, por exemplo, Foucault alude à população, não necessariamente está se referindo à soma de sujeitos de um território, e sim, o mais das vezes, a um objeto biopolítico, àquilo que, na forma de massa, estaria sob um controle de relações, mais ou menos, autônomo. A partir do momento em que o poder define-se como uma multiplicidade biológica, torna-se biopoder (um tema, em geral, um tanto quanto aberto ou em que o autor é consideravelmente incompreendido, podemos afirmar), o poder assume-se, além de um nível disciplinar, também em um nível orgânico de controle. Em suma, ele mostra que sempre há atravessamento de poder no sujeito e que o poder não está comprimido a nível de direito, e sim, a nível de mecânicas disciplinares ou biopolíticas.

Quando, por exemplo, Baudrillard, tratando do que chamará de algo na "sombra das maiorias silenciosas", refere-se à "população", explorando o conceito de "massa" como "neutra", não necessariamente afirma que a massa é algo desprovido de energia social. Ao contrário, para Baudrillard, a massa seria cheia de energia social, esperando tão-somente o momento certo para protagonizar a história, o seu status de poder. Ou seja, há o atravessamento de poder no sujeito, do mesmo modo. Mais que isso, há uma potência qualificável nas massas, um poder em espera. E, do mesmo modo, não poderemos admitir em Baudrillard que o poder jazeria apenas a nível de direito (nomos). Tanto um quanto outro observa uma obsessão purificadora do poder - seja na degradação virulenta da História apontada por Baudrillard, pela corrupção, resíduos, poluição publicitária, social, étnica, racial, etc; seja em políticas eugenístas, higiênicas, profiláticas sobre as massas, quando a vida se torna um elemento do político, em Foucault André Duarte (2206), no ensaio Biopolítica e resistência, lembraria o 
nazismo e o stalinismo como o ápice desse desdobramento, foucaultianamente, "biopolitizador").

Entretanto, se contrapuséssemos, grosso modo, os dois autores como criadores de enunciações inimigas, raciocinando na pura essência da relação entre massas e poder, nós poderíamos, por outro lado, reforçar as diferenças entre eles. Diríamos, assim, de outro modo, que, enquanto Foucault articula o homem como aquele que toma sua função-sujeito no interior de uma sociedade dada, resumindo-se a um coadjuvante do espetáculo espontâneo da história, Baudrillard estaria a proferir o oposto, que a massa é uma absorção do espetáculo, dos estereótipos, não tendo jamais nenhuma "vontade política". Diríamos, então, que, para Foucault, a massa é pura ordem de poder, o sujeito encena, e que para Baudrillard, pura desordem de poder, o sujeito obsceno (fora de cena), o que poderia ser um grande equívoco interpretativo, mesmo este segundo atentando para o fato de que a massa jamais se organiza, ela é non sense, caos, falência dos poderes e da condução cristalizada dos sentidos. Ambos os autores, enfim, trabalham com a noção de poder no social de um modo quiçá muitas vezes semelhante, é o que este artigo terá, ou proporá, como pano de fundo. Por exemplo, quando eles postulam que os sujeitos nas massas não possuem uma essência fixa, rígida, não sendo as massas, por sua vez, mistificadas, reprimidas em suas espontaneidades revolucionárias, pois, a bem da verdade, elas não são exatamente enganadas, manipuladas, pelo Poder (Foucault diria reprimidas por alguma “ideologia”). Elas seriam, para ambos, atópicas e não utópicas. Ou seja, as massas não possuiriam uma natureza representativa, mas se criam de dispositivos de simulação e de atuação dos sujeitos (sob “tecnologias de poder”, para Foucault). É assim que Foucault e Baudrillard pincelaram, por vezes, alguns contrastes entre o presente e o poder na Renascença, evidenciando que lá ele assumia mais a forma de um jogo, uma estética, um teatro, uma pintura, uma busca de virtuosismo, e não de uma verdade que reenviava a um sujeito. Apenas após a Revolução Francesa, o social triunfaria e se apoderaria do político e, aí, o "povo", como personagem novo, entrou em cena, neofigurado com uma suposta vontade política no teatro do poder, coisa que Baudrillard criticará, mostrando que o marxismo, por exemplo, inaugurou o fim do político, qual seja, quando o político passa a ser o "espelho do social". Bem, o que este 
artigo fará não é exatamente um inventário completo dos desenvolvimentos de ideias semelhantes dos dois autores, mas sim um registro de como analisamos aspectos pontuais na questão da análise do poder. E, mais adiante, vamos analisar as aporias do discurso de Baudrillard no livro em que se voltou contra Foucault, Oublier Foucault, no qual tentou desmontar a literatura foucaultiana acerca do poder, explanando essa literatura como, ela mesma, uma espiral generativa de poder.

Em entrevista, publicada no jornal Correio do Povo, de Porto Alegre, relemos Jean Baudrillard a falar sobre sua crítica à noção de poder foucaultiana:

A análise do poder feita por Foucault nunca o convenceu?

Jean Baudrillard - Não. Eu nunca pensei que se tratasse de uma análise pertinente. Para mim o fundamento do poder desapareceu pela volatilização do político. Era inútil, portanto, ir buscá-lo nas manifestações microscópicas do cotidiano. Ressalva que faço também à microfísica do desejo de Deleuze e de Guattari. É muito bonito, embora corresponda a uma fase ulterior da mesma lógica, quando estamos, na minha opinião, além disso tudo, o que se pode ver observando o desenvolvimento da cena política, uma zona morta, pela qual ninguém mais se interessa e mesmo as referências a Berlusconi e o poder audiovisual desintegram-se com facilidade. O terreno político está liquidado. Lidamos não com a perpetuação do poder sob uma outra forma e sim com o seu desaparecimento. A leitura de Foucault era definitiva e demasiado abrangente para ser verdadeira. Tínhamos que atravessá-la ou tomar um caminho transversal. Tentei fazê-lo, não contra Foucault, e pensei mesmo em defendê-lo quando o "politicamente correto" censurou-o a propósito de usa posição no caso do Irã (Baudrillard, 2013, s/p).

Foucault para o senhor fez uma crítica da modernidade ou do capitalismo? A questão faz sentido na medida em que muitos marxistas, após a queda do socialismo soviético, redescobriram Foucault, antes condenado, $e$ assumiram boa parte de suas posições.

Jean Baudrillard - Os arrependidos são muitos. Os pósmodernos reivindicam a herança de Foucault. Os marxistas em busca de uma nova roupagem também. Tudo isso faz parte da ordem da recuperação das coisas e das operações intelectuais fraudulentas. Mas Foucault não construiu uma crítica do capitalismo; ela é mais interessante. $\mathrm{Na}$ medida em que não estamos mais em uma situação típica do capitalismo falta-nos um instrumento de reflexão adaptado, não ao póscapitalismo, mas aos dados novos, pois saímos de um sistema de produção, de penúria ou de falta e entramos na extrema realidade. Precisamos descobrir a maneira de pensar os fenômenos extremos. A estratégia de Foucault 
era paradoxal e, contudo, necessitamos de algo ainda mais entranhado no paradoxo. Já o situacionismo, que era forte, perdeu a validade por ser radical, do Sujeito crítico, sem explorar o paradoxal. Precisamos de uma radicalidade objetiva derivada diretamente das coisas. Eis o meu problema. Foucault não me inspira na atualidade (Baudrillard, 2013, s/p).

Até certo ponto, Baudrillard defende, como que solitária e persistentemente, que o que deveria constar em Foucault e Deleuze seria antes o "desaparecimento do poder", do que a elaboração de uma outra modalidade de se assistir o poder². Mas, evidencia que não quer estar contra Foucault, demonstra perceber muito bem a potência de ordem paradoxal que ele suscita como estratégia radical, por mais que considere a sua própria metodologia como dada a mergulhos mais profundos nos paradoxos do presente. Foucault não o inspira na atualidade, e nunca o inspirou, apenas pelo fato de seu problema ser de outra ordem, queremos crer, de uma ordem que ainda não consegue desconfiar/esquivar totalmente da dimensão do político. Vejamos: ao propagar a bandeira do

2 Lembro, aqui, o meu livro, Dissonâncias de Foucault, no qual abordo os paradoxos da militância foucaultiana: "Em 61, defende sua tese doutoral $A$ história da loucura na Idade Clássica, momento em que faz um enorme e imediato sucesso; logo conhecerá Deleuze e entrará para o conselho de redação da revista que Bataille fundou, Critique, momento em que - ainda 3 anos antes de lançar As palavras e as coisas - publica $O$ nascimento da clínica. Deleuze foi para ele a janela de uma inovadora cumplicidade teórica, tanto que, sabidamente, logo empregarão juntos a publicação da edição francesa das obras de Nietzsche. Entretanto, em todo este tempo, onde em Foucault já temos a dimensão de uma obra original cujas diretrizes básicas marcarão toda sua produção futura, não podemos ressalvar uma participação militante mais intensa do autor. Se houve, foi mais como um combatente do que como um ativista gauche. Considerando-se abertamente um "diagnosticador do presente", Michel Foucault apreende em Nietzsche a atividade clandestina primordial da filosofia. De modo que o afazer em questão, dentro de todo conjunto de suas análises, vem a ser o de um mirar-se a si mesmo deslocado do seu tempo, em busca de restituir à atualidade suas próprias patologias e instabilidades as quais já estamos a par. / O primeiro paradoxo do engajamento em Foucault estaria no ativismo teórico com a questão ontológica da própria linguagem e da própria épistémè. Foucault não quer imobilizar o passado, ele marca-se na pontaria de uma nova preocupação ética com relação às minorias, cujas práticas, sejam religiosas ou sexuais, são o "alvo" da memorização, momentos em que memorizar é moralizar. Italo Tronca, em artigo chamado "Foucault e a linguagem delirante da memória", pergunta-se sobre qual a diferença entre história e memória em Foucault, ou melhor, qual seria o lugar do delírio nesta diferença? Explica ele que a memória geralmente está na ordem (des-ordem) de uma linguagem delirante - memória-involuntária. A História, o mais das vezes, é um lugar de apagamento da memória como linguagem delirante para dar vez a uma linguagem contínua - memória-conhecimento. Explica-nos, ainda, que para Foucault a linguagem é "transgressão pura", embora não seja uma categoria psicopatológica como o delírio, ela é delirante. No problema ontológico sob a limitação da natureza lingüística, a questão central estaria no fato de que a estranheza da existência é efeito da estranheza dos signos, a loucura da linguagem. Para Foucault: "a estranha existência da linguagem, digamos, à margem da matéria - nem bem uma coisa nem plenamente 'significante' passa como sendo constitutiva do Ser" (Gomes, 2012, p. 103-104). 
fim do político não estará Baudrillard ainda refletindo uma busca política, enquanto Foucault fazia uma micropolítica? Ou, se não acabou refletindo, quem sabe, sim, acionando certo simulacro do político? Esse mesmo político que ele afirma ter desaparecido, mas que em sua escrita acerca Foucault aparece cobrando um reaparecimento de si. De todo modo, percebemos uma radicalidade de questionamentos em Baudrillard bem mais objetiva, material. Independentemente da possibilidade de se acreditar que poderíamos ler em toda obra de Baudrillard uma inspiração foucaultiana, navegando aqui contra as suas próprias palavras, para tentar desestabilizá-lo do mesmo modo como ele tentou desestabilizar Foucault, temos que respeitar essa lógica de uma radicalidade objetiva que ele impõe como ação. No entanto, não acredito que Foucault tem ou teve uma ação intelectual menos eficaz, sociologicamente falando, do que Baudrillard.

O que vemos nos inúmeros livros de Baudrillard - como $A$ transparência do mal, O sistema dos objetos, América, Simulacros e simulação, Tela total ou A sombra das maiorias silenciosas - é que não passam de coletâneas de ensaios sedutores que, tal como Foucault, propõese obcecados pelo presente, pela fragmentação do poder no agora, e de modo tão aparentemente fascinante, anárquico e cheio de uma lógica interna tão poderosa quanto à censura que ele propõe versus Foucault. É neste ponto que, desde aqui-agora, sugerirei uma fixação na crítica que se traça contra a literatura de Foucault, para pensar não apenas até que ponto ela é válida, mas para notar nessa mesma crítica seus próprios nós e suas amarras, suas forças e coações, contra uma visão de poder que anda em Foucault. Assim farei para que possamos ler tanto Baudrillard versus Foucault quanto Baudrillard lado a lado ao seu oponente. Ambos "face-àface, tête-à-tête". Carecemos resguardar essa espécie de "amizade-inimiga" (diria Blanchot) que existe entre eles. Para tanto, obviamente, temos que checar, minuciosamente, o livro em que, como intelectual francês analisando a complexidade da noção de poder naqueles anos 70 , ele se articula na distância do mito-Foucault - obra que se intitula: Oublier Foucault. 


\section{A CULPABILIZAÇÃO GENEALÓGICA DE FOUCAULT}

Baudrillard reprochará as possíveis limitações na noção foucaultiana de "poder". Ou melhor, criticará acerca da necessidade de reatualização da análise do poder desde Foucault. Se o filósofo, tão silencioso e ao mesmo tempo com um megafone nas mãos, por um lado, dizia que o poder não é verticalmente localizado em uma instituição, em uma noção estrutural, etc, por outro lado, mostrava o poder como uma situação estratégica que regula o campo social. Porém, para Baudrillard, quem sabe essa noção advenha de uma visão exageradamente funcional no contexto da produção de uma era dos extremos. Seria funcional, posto que se estivesse esquivando do real, indo ao hipereal, deixando de encarar o poder como poder mesmo para virtualizar-se como uma noção paralela ao próprio presente. Nesse hiato, nesse espaço vazio, que Foucault permaneceria ao abandonar o passado ao próprio passado, o velho poder ainda se propaga, se desequilibra, desarticulada e paradoxalmente. Não é tão invisível, fragmentado, como quereria Foucault, está, todavia, mais visível que nunca como apoteose de seu conjecturado fim. E ele não é mais um poder moral, e sim um poder da catástrofe, catástrofe do poder sem fim. Portanto, é o que ocorre quando Baudrillard diz que "o terreno político está liquidado. Lidamos não com a perpetuação do poder sob uma outra forma e sim com o seu desaparecimento".

Mesmo sendo "pulverizado", "molecularizado", lido por uma ótica microscopista e genealógica, o poder em Foucault, segundo essa instigante crítica, dar-se-ia exageradamente como acepção depurada e enquadrada em uma polaridade histórica, estruturalizante, transmitindo-se, erroneamente, como um nexo insuperável:

Deseo e intensidad continúan siendo nociones/fuerza, el
poder en Foucault continua siendo, incluso pulverizado,
una noción estructural, una noción polar, perfecta en su
genealogía, inexplicable en su presencia, insuperable a
pesar de una especie de denunciación latente, entera en
cada uno de sus puntos o punteados microscópicos
(Baudrillard, 2001, p. 55).

Para Baudrillard, a genealogia como método em Foucault é ainda utópica, deixa escapar a questão de que o poder está em vias de morrer. Uma morte que o faz propagar no silêncio. Mas, o que Baudrillard quer exatamente dizer quando afirma que o poder não se dá tão-somente 
pulverizado, mas também "pulverulento"? Que poder luminoso é esse que estaria minado por uma reversão, uma morte, que Foucault não poderia enxergar genealogicamente? Baudrillard, em A transparência do mal, propunha o poder como qualquer coisa que atravessa as massas e que as coloca em uma zona indiferenciada, pantanosa, força de rejeição ao político, aversão ao poder. Dizia que "o poder fundamenta-se muito na aversão" (1990, p. 81). Será neste ponto que a maneira com a qual Baudrillard conserva a noção de poder inclui uma obscenidade que Foucault renega? Haverá uma maldade no poder que Baudrillard observa como qualquer coisa passível de ser colocada em uma tática de aversão, mas que em Foucault já não pode ser assim feita. Baudrillard conserva o mal vendo em Foucault uma dissimulação do poder que já não é mais algo abominável, logo já não é mais poder especificamente. Parece-me que o poder para Baudrillard, quer queiramos ou não, é sempre promíscuo.

Mesmo que, para Foucault, a genealogia representasse uma pesquisa contra discursos englobantes, memorializantes, depurados por instâncias hierarquizadoras do saber - no objetivo de, na luta contra isto, reativar memórias locais, descontínuas, etc -, o autor de Oublier Foucault enxerga nesse método um mero retorno quem sabe positivista de um artifício que, apesar de revolucionário, continua centralizador, pleno de efeitos de poder. Em Baudrillard, a promiscuidade ainda existe na sinergia do político, na intoxicação coletiva da massa. Ele vê, então, uma parte maldita em Foucault, na culpabilidade que ele possui, no que tange uma recusa da moral política, como se essa já estivesse acabada ou inexistente. Baudrillard fala em "transpolítica", ou daquilo que soçobra em um mundo onde o mal, já não mais podendo ser enunciado, simula sua ausência, sua fantasmagoria, quando na verdade está em toda parte. Por outro lado, as massas, para ele, isso que se denominou "massas" e que cresceu na obscuridão do político, qual uma virulência à política, constituem uma parte secreta de poder, mesmo sem essência alguma. As massas deixam, precisamente, que pensem que são alienadas, secundárias, é a contraordem, a superioridade das massas. Baudrillard buscou avaliar, nesse ponto, a questão da alteridade: "O segredo do outro é que nunca me é dado ser eu mesmo e que só existo por declinação fatal daquilo que vem de outro lugar" (1990, p. 175). As massas não têm vontade própria, não têm mais nada com 
a extradição do político. A extradição do outro seria uma utopia cristã equivocada, imperando constantemente na contemporaneidade, quando o indivíduo vai tornando-se responsável por sua própria vontade, por sua responsabilidade, servo de um poder de si (um “cuidado de si”?). Nesse assunto, Baudrillard vê que o método genealógico quem sabe subestima que nas relações de poder há toda uma dinâmica da alteridade. De tal modo, a genealogia não teria tanto sentido, sendo ainda instrumento engendrador de poder:

Eu continuo a pensar que o construtivismo do pensamento de Foucault, mesmo se ele é muito crítico, na sua ligação com Nietzsche, produziu uma reflexão radical, mas que é ainda um instrumento de poder intelectual. Ele fez uma excelente análise do poder, mas terminou por ser a encarnação mesma do poder (Baudrillard, 2013, s/p).

Sabidamente, a genealogia como método trabalha a partir da dispersão, logo, ela não pode se posicionar na velha linha contínua da história. Judith Revel, diagramando alguns conceitos essenciais de Foucault, não pode deixar de citar a genealogia como um enfoque que não é apenas um empirismo. Para ela: “o método genealógico é, portanto, uma tentativa de desassujeitar os saberes históricos, isto é, de torná-los capazes de oposição e de luta contra a ordem do discurso" (Revel, 2004, p. 52).

Que se critique um excesso de determinação apolítica em Foucault seria compreensível, no sentido em que nesse momento de um segundo Foucault, menos arqueológico e mais preocupado com relações de poder sobre os corpos, naturalmente os objetivos foucaultianos giram mais em se instituir uma visão que não se iludisse com os antigos modelos de análise histórica. Ou seja, Foucault queria mais repolitizar as políticas do poder do que bancar uma política do poder (como quer indicar maleficamente Baudrillard). Mas, tal genealogia sempre esteve, de algum modo, presente no autor. Assim, Baudrillard caminha à sombra silenciosa do outro, culpabilizando-o por determinado empirismo genealógico, como se assim fosse, como se fosse admissível retirar Nietzsche da inspiração de Foucault; enquanto, bem sabemos, o seu próprio trabalho investigativo não poderia surtir efeito algum se víssemos o poder ainda nos antigos moldes de análise materialista. Quem se esquece de Foucault é, desse modo, Baudrillard, mesmo atracado inconscientemente à lembrança dele, todo tempo, a produzir sua leitura sociológica da era dos extremos. Baudrillard voa, 
completamente, do contexto em que o autor estava inserido em sua época, sob uma missão definida e importantíssima para a intelectualidade filosófica, embora coincidente com aspectos histórico-sociais que também influíram outras diversas teorias sociológicas e legais. A fuga de um discurso coercitivo, naquele momento das análises do poder, era uma postura impactante que precisava ser realmente frontal. Diferentemente, Deleuze, notando esse contexto, falava-nos que: a passagem do saber ao poder, no rol de interesses foucaultianos, não se tratou tão só de uma súbita alteração temática, e sim de toda uma inovação arquivística sobre as relações de força, sobre a dimensão do poder.

Acredito que Baudrillard acaba por cobrar de Foucault uma lógica que não pode ser especificada, ao menos, em dois sentidos. Primeiramente, no sentido em que essa crítica só se assume dentro da lógica do próprio Baudrillard à sombra de Foucault. Está a culpar Foucault por uma aporia (menos frontal) que jamais poderia ser de ordem nietzschiana, assim, pondo-se na dimensão de poder de discurso que o próprio Foucault não faz mais do que renegar. Depois, no sentido de que, dentro daquele contexto da criação das condições do pós-estruturalismo, a busca de Foucault era a de ultrapassar teorias dialéticas ou revolucionárias, vanguardistas, que já estavam a não surtir tanto efeito no universo tanto prático quanto teórico. Assim, por exemplo, Foucault nunca se revelou um anarquista abertamente.

Por que Foucault se sentiria culpado por ser o espelho da noção de poder que descreve? Ora, como cobrar rastros de estruturalidade na literatura foucaultiana, quando Baudrillard justamente critica a generalização que surge com o pós-estruturalismo? Está certo que o texto Oublier Foucault foi produzido ainda antes dos anos 80 e já manifesta uma perspectiva de questionamentos (como catástrofe do real, hiperealidade, transparência, etc) que irá marcar futuramente o seu trabalho. E, cada vez mais, o trabalho de Baudrillard insistirá em uma dimensão isolada de análises que andam tanto por uma investigação das velhas aberrações no presente quanto pelos mais novos fenômenos extremos. Porém, então, o que ele faz, ao culpabilizar Foucault, será menos aniquilar a intelectualidade genealógica do autor, do que, antes, criar condições de se tentar vê-lo na extremidade do seu próprio discurso. Condições tais que são de total responsabilidade de Baudrillard, e não de Foucault, a meu ver. A 
culpa é mais de Baudrillard. Ele prefere encarar que não estamos mais em um período de produção de poder, mas de pura reprodução, no contexto do ultra-real, da prótese total. Porém, também a meu ver, esquece-se da relevância do debate que Foucault abre a partir de sua própria incumbência como intelectual e da anarquia que a sua noção de poder instaurava na própria tradição.

\section{ANARQUIA CONTRA UM SABER JÁ ANÁRQUICO}

Mas, voltamos a uma antiga questão, por que Foucault nunca se denominou abertamente um anarquista? Veremos. Margarete Rago começa seu livro Foucault, história \& anarquismo com uma cita de Deleuze:

Acreditar no mundo é o que mais nos falta; nós perdemos completamente o mundo, nos desapossaram dele. Acreditar no mundo significa principalmente suscitar acontecimentos, mesmo pequenos, que escapem ao controle, ou engendrar novos espaço-tempos (Deleuze apud Rago, 2004, p. 4).

Quero discorrer a partir dessa cita porquanto parece que Baudrillard está reivindicando um Foucault cujo saber melhor se reapossasse do mundo, um Foucault que deveria ser esquecido porque, de algum modo, não escapa ao controle que ele mesmo investiga microfisicamente no mundo. Ou, quem sabe, ao contrário, reivindicando um Foucault que se desapossasse do mundo ainda mais? Porque o que Foucault faz é, precisamente, em meu entender, suscitar novos acontecimentos de discurso, e talvez, nessa percepção ampla do poder microfísico, o que advenha incida na estranha impossibilidade de deixar de submeter-se completamente a um controle. Baudrillard não peregrina totalmente em vão pelas culpas de Foucault, pelas rachaduras, mas também não faz questão de lembrar que resistir ao controle é, em Foucault, ainda, lidar com o controle, operar controle, operar a relação saber\&poder. E há uma potência anárquica nisso. O que soçobra não é a pura inércia como quer notar Baudrillard.

Estamos justamente reincidindo no objetivo do próprio Foucault, que foi o de potencializar, cada vez mais, a relação poder\&saber. Foucault dizia que "o poder, longe de impedir o saber, o produz" (1999, p. 148). Há poder sim em tudo que Foucault fala e sabe sobre o próprio poder, ele está plenamente consciente do fato, aliás perguntemo-nos: qual o pecado nisso 
se Foucault foi um dos primeiros pensadores a proferir que o discurso é sempre poder? Acontece que Foucault não esquece ou apaga, subitamente, uma velha noção de poder, como quer Baudrillard em Oublier Foucault, ele simplesmente a dilata, tira-a de um estreitamento perigoso e restrito: ver o poder apenas como prática ideológica ou prática policial. Acaso a anarquia de um discurso sobre o poder não poderia estar transbordante de poder?

Lembremos de $A$ microfísica do poder, quando o autor nos diz:

\begin{abstract}
Não se trata de libertar a verdade de todo sistema de poder - o que seria quimérico na medida em que a própria verdade é poder - mas de desvincular o poder da verdade das formas de hegemonia (sociais, econômicas, culturais) no interior das quais ela funciona no momento. [...] Em suma, a questão política não é o erro, a ilusão, a consciência alienada ou a ideologia; é a própria verdade (Foucault, 1999, p. 14).
\end{abstract}

Poderíamos tentar desmontar Baudrillard reiterando que a questão, portanto, não está em uma ideologia mais equitativa ou menos equitativa, mais política ou menos política, mais poderosa ou menos poderosa, que o intelectual deve suster. A questão está no regime institucional de produção das verdades. O problema de Foucault vai bem mais abotoado a esse tentar constituir um olhar político com relação direta ao que constrói a verdade nas sociedades. Se essa relação direta incide pela microfísica a questão é, logo, enfrentada. Baudrillard, por sua vez, muitas vezes restringe Foucault a uma leitura da verdade como se esta fosse meramente circularizada, capilarizada e estrutural, em procedimentos ainda regulados pela produção. Como se Foucault não notasse sua própria especificidade. Como se reproduzisse um simulacro de poder, sem o saber.

Outra questão: estará Baudrillard lendo ironicamente o autor enquanto um anarquista utópico? Ou estará a propor que ele deveria, em seus efeitos desestabilizadores à velha concepção de poder, ter procedido ainda mais anarquicamente? Provavelmente sim, a segunda questão caberia melhor. E para salvá-lo da armadilha de Baudrillard, precisamos urgentemente, então, observar melhor a anarquia de seu discurso, ou antes, notar as analogias entre o anarquismo e a palavra foucaultiana que conduz a uma nova ideia de poder, em dada conjuntura do pensamento francês.

Como lemos no livro de Salvo Vaccaro, Foucault e o anarquismo (1995), Foucault sempre teve um pé no anarquismo, mesmo que suas remissões a isso fossem oscilantes e imprecisas. Margarete Rago lembra 
que "nem todos anarquistas se dizem foucaultianos, com algumas poucas exceções, nem Foucault se quer anarquista” (2004 p. 10). Pode-se ler o pósestruturalismo, em suas operações descentralizadoras, como uma "forma contemporânea de anarquismo", como defende Todd May (apud Rago, 2004, p. 15)... Edson Passetti, por sua vez, afirma que:

Foucault, por diversas vezes, apartou-se da classificação de anarquista, incluindo uma extravagante e acadêmica que o denominou um anarquista de esquerda. Pretender vincular diretamente o anarquismo e Foucault é se propor a andar em círculos tentando apanhar o próprio rabo, que devido a tantos giros termina ferido e fedido. Os escritos de anarquistas contemporâneos que se aproximam de Foucault mostram certa intimidade no campo da atitude demolidora na fronteira. O poder entendido como relações de força desloca e desassossega a herança liberal e socialista que entende o poder como decorrência dos efeitos de soberania e de seus desdobramentos jurídico-políticos. Relações de poder não são práticas apanhadas pelo pensar, domesticada e instrumentalizada segundo o melhor dos lados que governa o Estado. Poder em Foucault é uma prática que sedimenta autoridades em posicionamentos, em movimentos que percorrem a vida na casa, no trabalho, nas relações amorosas e sexuais, na pesquisa, e que provoca resistências, práticas correlatas e múltiplas que podem nomadizar existências, provocando contraposicionamentos, heterotopias, heterotopias anarquistas que realçam suas histórias e que dispensam o bolor acumulado advindo do culto aos registros da história passada (Passetti, 2006, p. 110-111).

Rago também lembrará, de modo crítico, José Guilherme Merquior, autor que elencou momentos de um Foucault "neo-anarquista", em suas críticas à utopia política ou no modo com o qual se conferiu sua militância contra quaisquer bases institucionais, contra toda forma de ordem, até mesmo a ordem revolucionária. E Salvo Vaccaro adverte, dentre vários outros rótulos anarquistas imputados ao autor, para as palavras da feminista Kate Soper que o titularia de "anarco-existencialista". A proposta de Rago nos ajuda a ir além de Baudrillard - além do anarquismo de Baudrillard versus Foucault, podemos dizer - porquanto é uma proposta de não enquadrar Foucault, não o restringir a uma disposição política ou apolítica, histórica ou a-histórica. Nesse sentido, ela respeita plenamente a célebre frase do filósofo: "não me pergunte quem sou, não me diga para permanecer o mesmo". Por conseguinte, Rago nos proporciona uma 
convergência entre as renovações foucaultianas da concepção de poder e as concepções libertárias da intelectual romana Luce Fabbri.

Luce Fabbri (apud Rago, 2004), em suas produções que, já antes de Foucault, articulavam discussões plurais, vagando entre os campos da história, poesia e política, revela-se, tal como o filósofo, uma anárquica “crítica do poder”. Entretanto, ao contrário do não-lugar de identificação foucaultiana, ela buscará filiar-se objetivamente ao anarquismo. Talvez, Foucault seja mais nietzschiano com o cultivo de uma genealogia, indo contra toda memória fiscalizada pela História, pela Antropologia. O que não impede Margarete Rago de destacar, brilhantemente, que muito do que Foucault propôs como obsessiva superação, como busca supra-histórica (superação do passado, da sacralização da memória, etc, visando sempre um trabalho de diagnosticador do presente), por vezes, incidia em indagações que a pensadora italiana propunha sob uma postura militante mais extrema.

Vamos à caça do anarquismo como pressentimento político da agoridade, como um discurso libertário no vestígio do instante. Tal investigação do aqui-agora significa "sentir o presente em vista de algo, em vista de uma finalidade, quer dizer senti-lo libertariamente em vista de uma liberdade" (Fabbri apud Rago, 2004, p. 20). Vejamos o que diz Rago:

Libertários, ambos fazem do poder em suas inúmeras manifestações e ramificações o principal alvo de ataque, procurando desmistificá-lo nos mínimos movimentos; no caso de Luce, a partir dos textos políticos e históricos em que aborda temas específicos; no caso de Foucault, criando sofisticados conceitos, que operacionaliza na análise da emergência histórica da prisão, assim como métodos de análise, a exemplo da genealogia da História. Trata-se, em ambos, de uma recusa da concepção jurídica do poder e da produção de um deslocamento que permite visualizá-lo nos múltiplos campos da vida social, enquanto positividade. Portanto, valorizam a "ação direta”, enquanto estratégia de resistência ao poder. Autonomistas, ambos se colocam como críticos radicais da representação política, entendida como delegação do poder a outrem e, assim, como recusa da possibilidade da tomada de decisões diretas, exercida em todas as áreas de atuação na vida social (Rago, 2004, p. 21).

No entanto, claro está na análise de Rago que, no fim das contas, a historiadora Luce Fabbri não atinge o mesmo grau de descontinuidade, de desmitificação, da identidade histórica, que a literatura foucaultiana talvez proponha muito mais radical e rupturalmente como prática libertária. Mas, 
sabemos que Foucault não se reconhece anarquicamente à margem da História e do passado, ao contrário, ele revitaliza um penser autrement, usufruindo da experiência histórica, todavia, para investigar a problemática da tradição do poder, visando a uma busca genealógica, antiantropológica, agonística, cheia de multiplicidades e paradoxos ${ }^{3}$. Assim, visa a triunfar contra uma dada noção de totalidade que Baudrillard quem sabe o reintroduz como metodologia poderosa ("maldita", em seus próprios termos) e quadriculadora.

É que é próprio de Baudrillard criticar o melodrama de toda rede, virtualidade, fragmentaridade, segmentaridade, micromolecularidade... E, logicamente, o sistema de Foucault seria quem sabe menos anárquico para ele, no sentido de que o filósofo se põe como um efeito-profilático à noção de poder. O problema está na insistência em notar a vertigem de Foucault como patológica. Vertigem que cria, revolucionariamente, um novo modo de poder, limpando ao extremo todo poder do passado, poder material, vertical, repressivo, etc, mas não deixa de ser material, é mera performance que simula não englobar o fenômeno fascinante do princípio do mal. Baudrillard, por sua vez, insiste em não querer observar que, na quebra foucaultiana da noção de experiência, de individualidade, etc, permanece a mesma quebra anarquista da noção de poder que fora operada antes de Foucault. Se Foucault é fascinante - esse discurso do Bem que em nada e nunca o afirma "salvador" - é preciso se reaprender a enunciar o Mal, e caímos na impossibilidade extrema, busca aquilo que no próprio Baudrillard não deixa de ser mera circularidade teórica. Tampouco

\footnotetext{
"Em Foucault, a voz (vozes) fala (falam); a escritura escreve, recorta: o sujeito ativista como suporte e efeito do combate. O bisturi estranho que recorta e, ao mesmo tempo, instala-se no corpus. Seu despreendimento sobrevém não apenas no modo um tanto quanto inseguro com o qual proferia o início de muitas de suas célebres conferências no Collège de France; ou no modo com o qual se desprendia de áreas, estatutos, estrados investigativos, etc. O diagnosticador não fala de um topos, está circulando. Seu despreendimento também se observa na dissipação deste recorte: enunciados decupados, ou, como dirá Artières, 'à maneira de um anatomopatologista com os cadáveres, ele corta os tecidos políticos e avança' (p. 30). Podemos ver bem a aguda diferença comparada à postura sartreana, na relação histórica que ambos tiveram com o GIP (Grupo de Informação sobre as Prisões), quando da atenção que os intelectuais da época, na França, voltavam com relação às revoltas que precediam a melhoria penitenciária daquele país. Foucault acredita em uma multidão de tessituras históricas e não em uma apenas História, nem por isso destrói a voz da História, continua, aliás, costurando-a ao seu modo, mas, por sua vez, toca o barco do presente para, como disse Philippe Chevallier, 'dissociar no lugar de unificar' (p. 49), o que lhe confere um sentido bélico de poder e liberdade do pensamento (no neologismo foucaultiano de 'agonismo'-'agonisme' - em contraposição ao termo 'antagonismo”' (Gomes, 2012, p. 108).
} 
Baudrillard está imune ao mal, ou promove o discurso salvador para o sujeito. Veja-se que, ao contrário do que ele pensa, Foucault não abandona o indivíduo a uma dimensão incoerente e inativa, esquecendo-se de alocá-lo no "simulacro" (no presente) 4 . O chamado "pensamento como ação" é o que nos faz recordar Margarete Rago e é o que nos ajuda a nos esquivarmos dessas críticas que o situam apoliticamente. Ou seja, muitos leitores críticos, contra Foucault, insistentemente...

se fecham para perceber um outro ponto bastante delicado e complexo, ou seja, a representação do espaço com que operam: espaço vazio, onde o sujeito se alocaria anterior e fora da História, nos bastidores. Nesse sentido, Foucault observa, ao falar dos "espaços de fora" (espaces $d u$ dehors) - como as utopias e heterotopias - que nós não vivemos no interior de um espaço vazio, no qual poderíamos situar os indivíduos, como se pensa comumente ao se falar do sujeito universal. Ao contrário, vivemos no interior de um espaço cheio de relações (Rago, 2004, p. 53-54).

O segredo da crítica de Baudrillard, quem sabe, permanece justamente no fato de propor uma anarquia contra um saber já anárquico. Ele se recusa, a toda lei, ver esse jogo de relações, de estratégias que ainda incidem materialmente; nega a possibilidade desse espaço que mesmo vazio, não está vazio. $\mathrm{E}$ aquilo que pode ser encarado como incoerência do poder em Foucault assim o é sempre a partir de uma postura aliada à universalidade do sujeito, coisa que não é mais possível acreditar lendo-se foucaultianamente. E, do mesmo modo rigoroso, Baudrillard persiste em exigir do trabalho de Foucault um quase outro arsenal anárquico que provavelmente o próprio autor descartou por não coincidir com a sofisticação do olhar com o qual passou a ver os novos impasses do poder. Foucault é um ultra-historiador. Se o filósofo passasse a ser alguma coisa como um sociólogo dos extremos, semiótico, quem estaria, aí, refletido nesse espelho, senão o próprio Baudrillard? Eis o domínio crítico em que, talvez, Baudrillard se envolva tão poderosa e anarquicamente em direção ao

4 Considerado um "diagnosticador do presente", é fato que Foucault jamais ignorou as variadas multiplicidades ativas que produzem, historicamente, o indivíduo. Conforme afirmou em certa ocasião: "A minha hipótese é de que o indivíduo não é o dado sobre o qual se exerce e se abate o poder. O indivíduo, com suas características, sua identidade, fixado a si mesmo, é o produto de uma relação entre o poder que se exerce sobre os corpos, multiplicidades, movimentos, desejos, forças" (Foucault, 1999, p. 161). 
autor de História da sexualidade. Baudrillard ao passo que nega o espelho, contraditoriamente, exige um espelhamento de sua teoria, ao invés de ver, no pensamento do outro, um outro pensamento a ser lembrado.

\section{A ESPIRAL DE PODER}

Passada uma era de poder caracterizada pela teologia - poder teológico (a caça divina do poder) -, deu-se a de um poder como noção teleológica (busca do fim, das regularidades, dos padrões). Foucault, conforme Baudrillard, vem enfim ajudar a determinar a concepção de um poder teleonômico:

Acabado el poder teológico, acabado el poder teleológico, iviva el poder teleonómico! La teleonomía es el fin de toda determinación final y de toda dialéctica: es una especie de inscripción generatriz anticipada, inmanente, inevitable, siempre positiva, del código, y que solo da lugar a mutaciones infinitesimales. Bien mirado, el poder en Foucault se parece extrañamente a "esa concepción del espacio social tan nueva como la de los espacios físicos y matemáticos actuales", como dice Deleuze, cegado de repente por las ventajas de la ciencia. Es precisamente esa complicidad la que hay que denunciar, o de la que hay que reírse (Baudrillard, 2001, p. 47-48).

Mas, a importância de Foucault é demasiado desfavorecida por Baudrillard. E ele o põe ao lado de Deleuze, muitas vezes no decorrer do livro, como se ambos estivessem reduzidos a um mesmo esquema topológico, sob as mesmas intensidades analíticas. Seriam intensidades que resumem todo tipo de relação de forças em fragmentação, em interstício, em uma intrigante multiplicidade sempre resultante em escala atômica e invisibilizante. O excesso de segmentaridade, de capilarização, que conduz à obsessão foucaultiano-deleuzeana sobre a constituição do poder e do desejo, acaba colocada em total coincidência. Como se o poder em Foucault não passasse do desejo para Deleuze. Se não há mais finalismo na velha visão do poder teleológico (visão doutrinária e finalística), a maneira de ver o poder que sobra é a teleonômica (visão maquinal das suas estruturas).

Creio que devemos repensar o papel intelectual e metodológico de Foucault com relação ao sujeito e ao poder, pois é contra isso que Baudrillard desfere farpas. Nos anos 8o, Michel Foucault e François Ewald (vulgo Maurice Florence) elencavam os princípios metodológicos foucaultianos - no verbete do Le Dictionnaire des philosophes. Dentre eles: 
como ponto de partida, era preciso urgentemente evitar os cerceamentos universais antropológicos a todo custo, interrogar o sujeito em sua constituição governamental, histórica, etc (elucida-se o perigo em propor o desaparecimento puro do sujeito, em favor de uma objetividade nova; mas não é o que ele queria fazer, está bem claro, ou melhor, não queria jogar-se em um abismo de novas verdades e sim, tentar uma história crítica inédita, na qual o domínio que divide discursos em verdadeiros ou falsos fosse, ao menos, mais transparente). No entanto, o que faz a crítica baudrillardiana vem a ser buscar as massas, não o sujeito, e assim, justamente, narra que Foucault não percebe esse mesmo perigo de supressão do político, em seus discursos sobre a sexualidade, enfermidade mental ou delinquência. Dos dois autores: quem está mais a generalizar e volatizar o político? Outro princípio era "el de dirigirse a las prácticas como um dominio del análisis: el acercamiento del estúdio de uno mismo desde el ángulo de lo que se hacia" (Florence, 1996, p. 7). Logo, essas práticas são entendidas como modos de atuar, de pensar, evidenciando os modos de objetivação do sujeito, em várias culturas, em vários procedimentos de poder. Foucault não pretende ser revolucionário no sentido de modificar o real, ele procura criar as condições de se investigar as bases do que consideramos objeto e/ou sujeito, as bases estruturais da alteridade que gera poderes, as "práticas" que fazem com que os sujeitos e os poderes existam.

Em verdade, o fato de a literatura filosófica foucaultiana ser sem happy end, não significa que tudo acabe em uma fascinante e contraditória parte maldita da filosofia, ou no vazio absoluto da política (como, por sua vez, lemos claramente no catastrofismo de Baudrillard). Quem reduplica ilusões, em muitos sentidos, talvez seja muito mais a intelectualidade motriz do próprio Baudrillard, o que explicaria como os textos deste autor são tão circulares e repetidores, como que sempre pressionando as mesmas teclas, sob modulações diversas, a ponto de eternamente reconvencer o leitor acerca da transparência desse $\mathrm{Mal}$, desse mundo em exigência do simulacro, em estado de virulência cínica.

A intelectualidade de Foucault, por sua vez, tem a função, a meu ver, de sabotagem desse Mal e não de mera reduplicação. O que antes considerávamos como papel político do intelectual, seja como representação do proletariado, seja como intelectual-perito, jamais passou 
de um papel de discurso marcado por poderes políticos invisíveis. Não é Foucault que invisibiliza o sujeito e os poderes que o atravessam, o objetivam. Foucault vai distinguir-se, numa circularidade que não repete. É como diz seu grande amigo Paul Veyne, "si hay algo que distingue el pensamiento de Foucault del de otros es el firme propósito de no caer en una repetición, de no reduplicar nuestras ilusiones" (Veyne, 1996, p. 53).

Acredito que o problema está na dificuldade de Baudrillard em visualizar o trabalho de Foucault como um trabalho em movimento. É fundamental que Foucault tenha analisado as repressões sociais para poder configurar, desde Vigiar e punir, por exemplo, um discurso sobre a relação entre poder e corpo que fosse mais amplo e mais além das implicações e restrições que a mera noção de repressão aportava consigo. Porém, de modo taxativo, Baudrillard sugere uma incoerência colocar a repressão e a ideologia em segundo plano, me parece. Ou, ao menos, quer apontar que nessa busca microscópica (para ele: teleonômica) - que supõe dessacramentar as generalidades como objeto e esquecer certas cenas em prol de investigar os cenários - no fim, acaba-se simplesmente por se retomar e exaltar a generalidade. Criticar, por exemplo, toda psicanálise, todo marxismo, toda jurisdição, todo político, pondo-lhes em uma aconchegada zona de apagamento. Para ele, ao tentar suprimir a noção de repressão do próprio poder, quem sabe, se está, apenas, a substitui-la pela noção de produção. Ao buscar as condições de poder que atuam sobre os espaços, esquecemos a própria repressão no espaço do poder, pois para o argumento de Baudrillard, toda liberação está fomentada pela repressão, liberação da palavra, liberação da própria palavra foucaultiana:

Lo que Foucault nos dice (mal que le pese) es esto: nada funciona por la represión general, todo funciona gracias a la producción - nada funciona por la represión general, todo funciona gracias a la liberación. Pero da igual. Toda liberación está fomentada por la represión: la de las fuerzas productivas como la del deseo, la de los cuerpos como la de las mujeres, etc. No hay excepción a la lógica de la liberación: toda fuerza, toda palabra liberada, es una vuelta más en la espiral del poder (Baudrillard, 2001, p. $35)$.

A tese de Baudrillard é que, assim, nessa procura teleonômica por se analisar o poder, o que se faz é, tão somente, reiterar o poder, circular por novos conceitos, na espiral de poder. Espiral de um poder, agora 
fantasmático, mas que continua a existir repressor em toda acumulação (de desejo, de palavra, de signo, de produção, de capital, etc). Se o poder irradia na religião, na sexualidade, na psicanálise, nos desejos, como fluxo incessante, não deixa de irradiar sempre de modo mercantil, como efeito de produção, de troca, de capital. Assim, Baudrillard recomenda uma reinversão, ao se ler a proposta de "liberação" em Foucault. Repressão e liberação são dois lados do mesmo imaginário, por vezes. Obrigação da fluidez, de se por em circulação a libido, o psíquico, mas que, para ele, nada mais significa que recair em valores mercantis, valores que necessitam ser disseminados ao infinito, simulacros daquele mesmo poder, ou noção de poder, que Foucault pautava. Ou seja, poder inevitável e irreprimível que funciona em todas as direções e em todos os lugares, sejam centrais ou heterotópicos:

En adelante ya no se dirá más: "Tienes un alma, debes salvarla", sino: "Tienes un sexo, debes encontrarle el buen uso." "Tienes un inconsciente, hay que saber liberarlo." "Tienes un cuerpo, hay que saber gozarlo." "Tienes una libido, hay que saber gastarla", etc., etc. Esta obligación de fluidez, de flujo, de circulación acelerada de lo psíquico, de lo sexual y de los cuerpos es la exacta réplica de la que rige el valor mercancía: que el capital circule, que ya no haya gravedad; punto fijo, que la cadena de inversiones y reinversiones sea incesante, que el valor irradie sin tregua y en todas las direcciones - es esa la forma actual de realización del valor. Es esa la forma del capital, y la sexualidad, la consigna sexual, el modelo sexual, es su forma de aparecer a nivel de los cuerpos (Baudrillard, 2001, p. 32-33).

Creio que o problema já está no início do livro Olvidar Foucault, ou seja, a interpretação de Foucault como sendo, escrituralmente, discursivamente, uma perfeita "espiral generativa de poder" (Baudrillard, 2001, p. 7) que se encadeia ao infinito. O que há de diferente, nessa espiral de poder, entre a metáfora política e a metáfora psíquica, quando agora cabe a cada um legislar sobre uma jurisdição sexual, corporal, como "prolongamento fantasmático da propriedade privada" (Baudrillard, 2001, p. 35)? O inconsciente, a libido, o psíquico, etc, como capitais, jamais devem deixar de estar em gestão, em circulação, em disseminação, na busca da liberdade, ou da libertação. A liberdade, portanto, dá-se como produto do trabalho, ou da gestão, sobre o próprio corpo, mente, sexo, libido, disciplina, etc... Mas, aí vem a armadilha, isto não seria mero 
prolongamento daquilo que Foucault negou como poder disciplinar, teleológico? Até que ponto é coerente esquadrinhar um poder como contrapoder no sujeito em si mesmo, quando replica ainda na lógica da própria produção exacerbada, difracção ao infinito, que sempre reaparece onde tudo é reativo?

Em A microfísica do poder, Foucault critica a maneira com a qual os intelectuais ditos de esquerda tomavam a palavra no interesse de tornaremse donos da verdade, ou seja, o poder do intelectual como poder de representação universal das massas. Lembra-nos que a figura do intelectual como portador da lei, da verdade, ante o proletariado, defensor das reformas sociais justas (destaca, por exemplo, Voltaire), advém menos de uma herança no sentido sociológico ou político e, sim, tem muito a ver com o sentido jurídico, posto que: “o intelectual 'universal' deriva do juristanotável e tem sua expressão mais completa no escritor" (Foucault, 1999, p. 11). Depois, teremos a passagem para um outro tipo de poder intelectual que é mais próximo daquele do cientista-perito, é um poder de especificidade (destaca, por exemplo, Darwin). O intelectual como personagem histórico de poder tem, basicamente, âncoras nesses dois estereótipos distintos para Foucault, acreditando que seu espaço-tempo é o de uma reelaboração da especificidade do intelectual. Já Baudrillard pensa que a era intelectual, em que Foucault está, se coloca, talvez ingenuamente, à margem de qualquer herança intelectual ou de poder intelectual, em um novo mundo onde o poder não tem mais nenhuma essência política:

O novo poder se quer cultural e intelectual. Ele não quer ser mais um poder histórico cínico, quer ser a encarnação dos valores. Tendo traído sua essência política, quer que os intelectuais, por sua vez, traiam a sua, e passem para o lado da reconciliação do conceito, quer que eles percam a duplicidade do conceito assim como eles perderam a duplicidade do político, e se deixem levar para o lado do real, na direção de uma discreta beatificação de suas esperanças, na direção de uma reconciliação polida do real e do racional, ou do real e do imaginário. Tal é o contrato que nos é proposto por este poder que não é um poder - apogeu da democracia, poder hipócrita da virtude - e nós fomos agarrados. Porque o intelectual infelizmente sempre é bastante virginal para ser cúmplice da repressão ao vício. Ele também não está à altura do exercício cínico, isto é, imoral e ambíguo do pensamento, assim como os políticos não estão à do poder (Baudrillard, 2004, p. 49). 
Mas, Foucault deixou claro que a verdade que um intelectual pronuncia é sempre localizada dentro de um poder, jamais existe sem poder. Foucault é, assim, consciente que seu novo papel intelectual é, ainda, um papel de poder, um papel poderoso.

Foucault é, para Baudrillard, puro espelhamento daquilo que ele mesmo proporia conteudisticamente. Foucault estaria seduzido a tal ponto pela sua descoberta simbólica acerca do poder que a maneira com a qual ele se apresentaria em termos de discurso é uma operação orbital, circular. É, assim, que Foucault é tomado na própria espiral do poder, pela ótica baudrillardiana.

\section{SOBRE A PROPOSTA CABAL DE ESQUECER FOUCAULT}

Ao ler Foucault, a maneira com a qual Baudrillard se distingue do modo de Deleuze ou de Blanchot está no fato de ele elevar, constantemente, a dúvida sobre o que o filósofo propõe tão perfeitamente. É querer romper essa espiral de poder, provocativamente. Se Foucault o incomoda tanto a ponto de criar um "outro lado", não se trata ainda de defender um lado ou outro. Com isso, quero dizer que não basta contra-criticar Baudrillard, e sim tentar fazer o que aqui estamos tencionando: investigar as aporias e os poderes, as espirais por onde passam as dúvidas e os questionamentos agudos baudrillardianos ao opor-se a Foucault. Creio que Baudrillard mantém um pé em Foucault quando o incômodo com o poder é um dos lugares que o discurso de Foucault prevê, propõe. É impossível afiançar, primariamente, que Baudrillard não captou, não entendeu, não apreendeu Foucault. Ou que, no tema do poder na era dos extremos, na pósmodernidade, o fez de modo menor. Não vou cair, finalmente, na armadilha, na condição de valoração, de escolha de qual dos dois é o caminho justo a lembrar. Lembrar o que permanece entre os dois autores é o que me exclui de esquecer Baudrillard.

Qual a contribuição, portanto, que Baudrillard dá a um foucaultiano mais fanático e defensivo ou mesmo a um leitor iniciante e oscilante de Foucault? Ele nos ajuda, penso, a entender que aquilo mesmo que Foucault apoia como conteúdo do dizer, naquilo que exprime em sua fase genealógica, não é nada que passe longe daquilo que ele faz, institui, poderosamente. Falamos de uma coerência enorme entre o que se diz e o 
ato de dizer, entre sobre o que se escreve e o ato de escritura, entre o poder do qual fala e o poder do seu falar. É aí que observo que o que baudrillardianamente se pode ler como uma grandíssima incoerência na literatura de Foucault, na espiralada escritura que flui inextrincavelmente seduzida pelas suas descobertas-invenções conceituais é, ao contrário, de uma incrível coerência. A ambiguidade está ali mesmo.

A diferença é que Deleuze, no livro Foucault, elogia a ambiguidade da literatura de Foucault como dispositivo mítico em um novo universo dos poderes. Tal ambiguidade assume, então, um caráter importante. Blanchot, em Michel Foucault tel que je l'imagine, resolve imaginar Foucault como um intelectual que deixa entrever os perigos de sua própria procura, nisso em que ele se confere igualmente um dispositivo mítico5. Outra vez, Foucault é um homem em perigo, lido por Blanchot, diante do poder que propõe. Já Baudrillard, observa o mesmo perigo, o vê em perigo, em ambiguidade, tal como Blanchot e Deleuze, mostrando os dispositivos de poder do qual ele fala, então, na transparência do seu próprio savoir-faire. No entanto tal ambiguidade, para ele, é apolítica. E, uma vez apolítica, é inconveniente.

Logo, nos voltamos ao título sobremodo cruel, pesado, árduo, de Baudrillard: Esquecer Foucault. Por que esquecer Foucault? Baudrillard não nos ensina outra coisa senão a importância de lembrá-lo. Vamos, com ele, (co)memorar Foucault o tempo todo, dos perigos do discurso, do pósestruturalismo, do Foucault que Foucault deveria lembrar (inclusive)... Logo, não há como: se esquecermos Foucault, imediatamente outro Foucault aparece, desponta desse vazio (dizendo "o que importa quem fala”), a presença deste apagamento, mesmo como nesse caso em Baudrillard, o que o exime de sua negatividade do esquecimento, ou talvez, pessimismo. Pois, afinal, posso refletir que Baudrillard não deixa de ser tão estratégico e estrutural, orbitante, circular, quanto o Foucault que ele quer

\footnotetext{
5 Blanchot observa a Foucault como: "um homem em marcha, solitário, secreto e que, por causa disso, desconfia dos prestígios da interioridade, recusa as armadilhas da subjetividade, procurando onde e como é possível um discurso de superfície, fulgurante, mas sem miragens; não um estrangeiro, como se acreditou, à procura da verdade, mas deixando ver (depois de muitos outros) os perigos dessa procura, assim como as relações ambíguas desta com os diversos dispositivos do poder" (Blanchot, 1986, p. 5, tradução nossa).
} 
esquecer ou (pro)pôr à sombra silenciosa. O que é a memória aqui? Como se lembrar, ou se esquecer, de um autor que não queria ser captado por nenhum dispositivo fixador, que costumava questionar em primeiro lugar o modo de subjetivação de um sujeito pensante, dizendo nunca estar a pensar a mesma coisa, razão pela qual seus livros seriam "experiências", um autor que, reiteramos, dizia: "não me perguntem quem eu sou, não me peça para permanecer o mesmo". Foucault estaria tão apaixonadamente seduzido pelo poder (lembro que poder é sedução, e não produção para Baudrillard) que redunda nesse poder experiencial passado em sua identidade escritural, em seu estilo de dizer.

A censura baudrillardiana aponta uma aporia nos conceitos gerais de poder e de desejo, no pós-estruturalismo, como sendo nada mais que novos edifícios de produção. Estará Foucault vinculado imanentemente a uma inevitável produção escritural altamente acumulativa (e não descontínua, como queria), progressiva, institucionalizada, econômica, poderosa (no mal sentido), política, mítica, etc? Em que ponto essas críticas todas, ao falarem de Foucault, não se vinculam ou se seduzem também por isso? Certo. Essa pode não ser a questão que melhor nos livre, finalmente, da proposta de esquecê-lo. Botamos novamente um contra o outro. O propósito de Baudrillard recai no seguinte impasse: será o texto de Baudrillard mais sedutor do que produtor? Será sua lógica ineludivelmente uma refração acertada àquilo que ele se opõe: a existência "sublime" do poder microfísico?

Para Baudrillard: o poder é simulacro, o poder seduz, não produz. É preciso dessublimar o poder e não sublimá-lo. É sua diferença, o que tem a sobressair na comparação com o autor de Vigiar e punir. Terá ele nos aliciado o suficiente? Terá nos seduzido a esquecer, em termos de direito, do que nem mesmo ele esquece? Baudrillard é tão sedutor quando Foucault, não há dúvida.

\section{REFERÊNCIAS}

BAUDRILLARD, Jean. A transparência do mal: ensaio sobre os fenômenos extremos. Trad. de Estela dos Santos Abreu. São Paulo: Papirus, 1990.

BAUDRILLARD, Jean. Olvidar a Foucault. 3. ed. Trad. de José Vázquez. Valencia: Pre-Textos, 2001. 
BAUDRILLARD, Jean. À sombra das maiorias silenciosas: o fim do social e o surgimento das massas. Trad. de Suely Bastos. São Paulo: Brasiliense, 2004 .

BAUDRILLARD, Jean. Tela total: mito-ironias do virtual e da imagem. Trad. de Juremir Machado da Silva. Porto Alegre: Sulina, 2005.

BAUDRILLARD, Jean. Entrevistas Marcantes de Juremir Machado da Silva - Baudrillard e o virtual: "Jean Baudrillard, o apocalíptico tranquilo". Disponível em: <http://www.correiodopovo.com.br/blogs/juremirmachado/?p=4104>. Acesso em: 30 maio 2013.

BLANCHOT, Maurice. Michel Foucault tel que je l'imagine. Paris: Fata Morgana, 1986.

DELEUZE, Gilles. Foucault. São Paulo: Brasiliense, 1988.

DOSSE, François. História do estruturalismo. Trad. de Álvaro Cabral. Bauru: EDUSC, 2007. v. 2.

DUARTE, André. Biopolítica e resistência: o legado de Michel Foucault. In: RAGO, Margareth; VEIGA-NETO, Alfredo (Org.). Figuras de Foucault. Belo Horizonte: Autêntica, 2006. p.45-55.

FOUCAULT, Michel. Nietzsche, Freud e Marx. Cahiers de Royaumont 6, Nietzsche, Paris, Éditions de Minuit, p. 183-200, 1967.

FOUCAULT, Michel. História da sexualidade: o cuidado de si. Rio de Janeiro: Graal, 1984.

FOUCAULT, Michel. Microfísica do poder. 14. ed. Rio de Janeiro: Graal, 1999.

FOUCAULT, Michel. Verdad, individuo y poder. In: FOUCAULT, Michel. Tecnologias del yo. Trad. de Mercedes Allendesalazar. Barcelona: Paidós Ibérica, 2000. p. 141-150.

FLORENCE, Maurice. Foucault, Michel, 1926 (-1984). Revista de Filosofia Anábasis, Madrid, ano III, n. 4, p. 3-8, 1996.

GOMES, Daniel de Oliveira. Dissonâncias de Foucault. São Paulo: Lumme, 2012.

NIETZSCHE, Friedrich. La Gaya Ciência. Madrid: Libsa, 2000.

PASSETI, Edson. Heterotopia, anarquismo e pirataria. In: RAGO, Margareth; VEIGA-NETO, Alfredo (Org.). Figuras de Foucault. Belo Horizonte: Autêntica, 2006. p. 109 -118.

RAGO, Margareth. Foucault, história e anarquismo. Rio de Janeiro: Achiamé, 2004.

REVEL, Judith. Foucault: conceitos essenciais. Trad. de Carlos Piovezani Filho. São Carlos: ClaraLuz, 2005.

REVEL, Judith. Pensamento vertical: uma ética da problematização. In: GROS, Frédéric. (Org.). Foucault: a coragem da verdade. Trad. de Marcos Marcionilo. São Paulo: Parábola, 2004. p. 65-87.

SERNA, Justo. ¿Olvidar a Foucault? "Surveiller et Punir" y la historiografia, viente años después. Historia Contemporánea, n. 16, 1997, p. 29-46. 
Disponível em: <http://revista-hc.com/includes/pdf/16 04.pdf $>$. Acesso em: 25 maio 2013.

VACCARO, Salvo. Foucault e o Anarquismo. Rio de Janeiro: Achiamé, 1995.

VEYNE, Paul. El último Foucault y su moral, Anábasis - Revista de Filosofia, n. 4, p. 49-58, 1996.

Idioma original: Português

Recebido: 22/02/16

Aceito: 15/06/16 